Supporting Information for

Sequence selective hydrolysis of DNA using conjugates of $\mathrm{Zr}(\mathrm{IV})$ metal complexes and peptide nucleic acids

Felix H. Zelder, Andriy Mokhir, Roland Kraemer*

\title{
List of Schemes
}

Scheme S1. Synthesis of protected ligands 15-18.

\section{List of Figures}

Figure S1. MALDI-TOF mass spectrum of HPLC purified 1.

Figure S2. MALDI-TOF mass spectrum of HPLC purified 2.

Figure S3. MALDI-TOF mass spectrum of HPLC purified $\mathbf{5}$.

Figure S4. MALDI-TOF mass spectrum of HPLC purified 7.

Figure S5. MALDI-TOF mass spectrum of HPLC purified 8.

Figure S6. MALDI-TOF mass spectrum of HPLC purified 9.

Figure S7. MALDI-TOF mass spectrum of HPLC purified 10.

Figure S8. MALDI-TOF mass spectrum of HPLC purified 11.

Figure S9. ${ }^{1} \mathrm{H}-\mathrm{NMR}$ of 15.

Figure S10. ${ }^{13} \mathrm{C}-\mathrm{NMR}$ of $\mathbf{1 5}$.

Figure S11. ${ }^{1} \mathrm{H}-\mathrm{NMR}$ of 16.

Figure S12. ${ }^{13} \mathrm{C}-\mathrm{NMR}$ of 16.

Figure S13. ${ }^{1} \mathrm{H}-\mathrm{NMR}$ of 17.

Figure S14. ${ }^{13} \mathrm{C}-\mathrm{NMR}$ of 17.

Figure S15. ${ }^{1} \mathrm{H}-\mathrm{NMR}$ of 18.

Figure S16. ${ }^{13} \mathrm{C}-\mathrm{NMR}$ of $\mathbf{1 8}$.

Figure S17. Cleavage of DNAs 13-14.

Figure S18. Cleavage of ATC T and TAG TTG TGA CC (mixture VII). 
Description of the DNA cleavage reaction.

Description of the control experiment mixture VII.

Synthesis of protected ligands 15-18

Synthesis of PNAs 1,2,5, 7-11

Description of analytical HPLC of DNA cleavage reactions. 


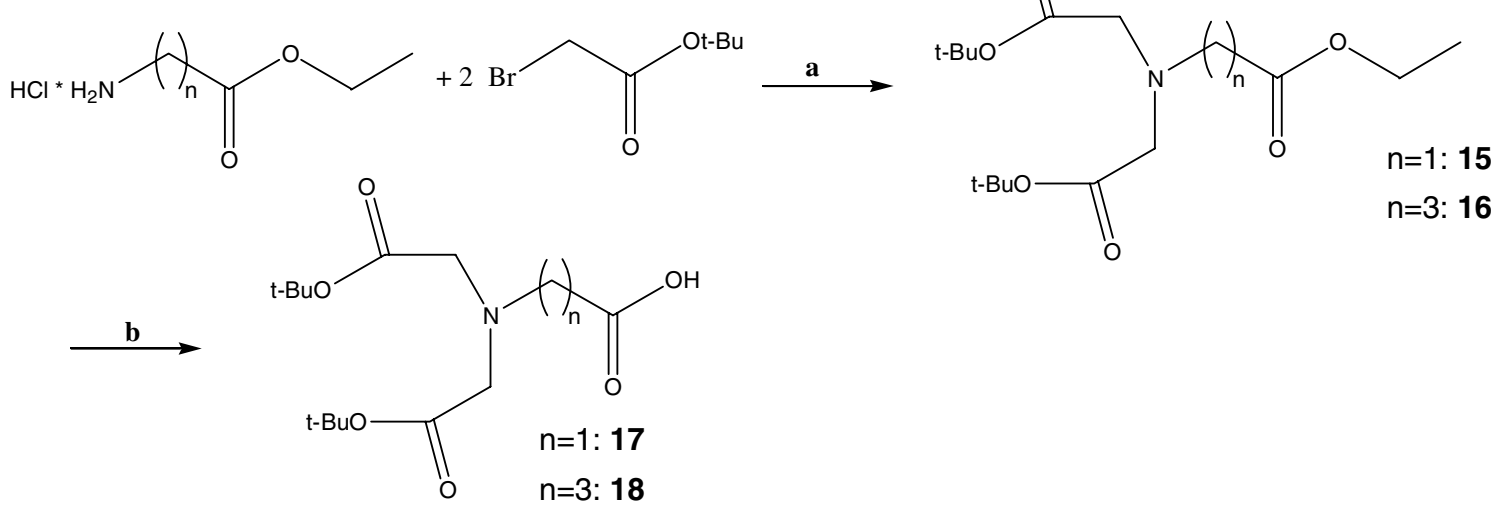

Scheme S1. a. DMF/ DIEA; $25^{\circ} \mathrm{C}$. b. 1) NaOH/ MeOH, 2)Dowex-Pyridinium.

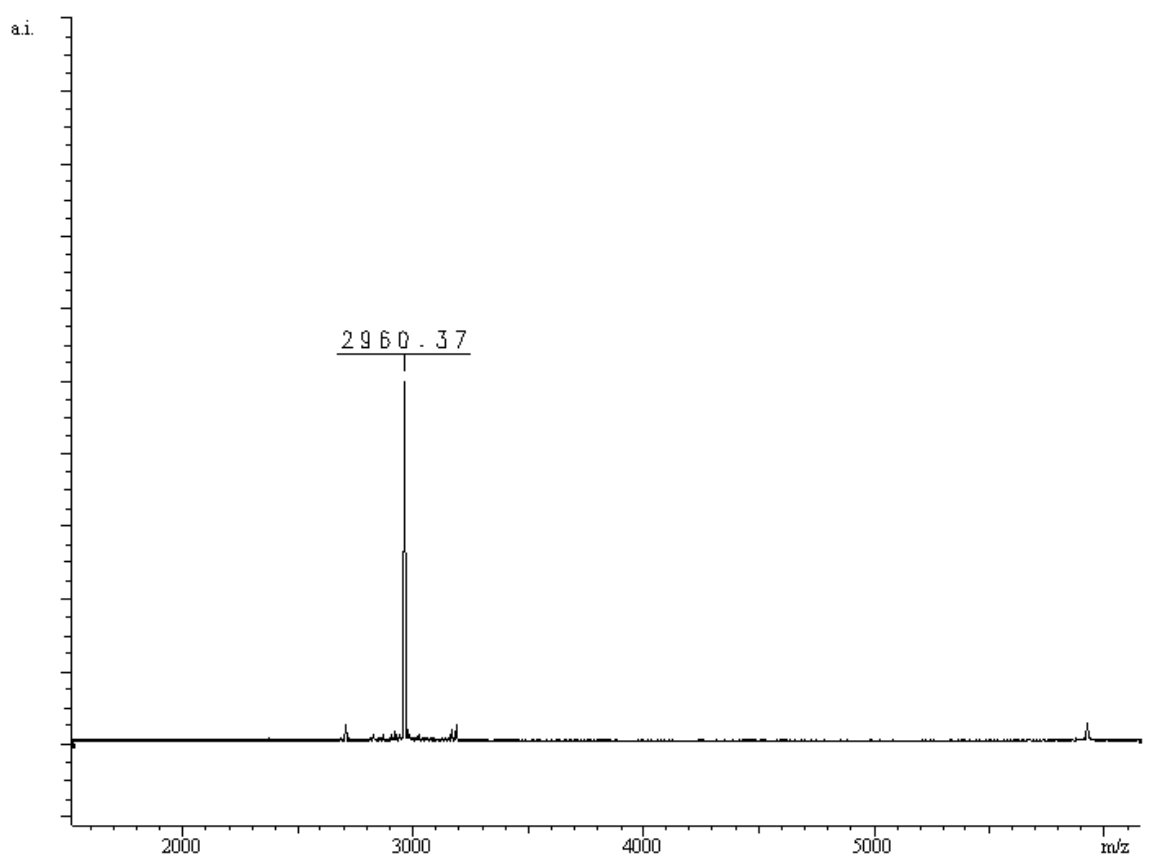

Figure S1. MALDI-TOF mass spectrum of HPLC purified 1. 


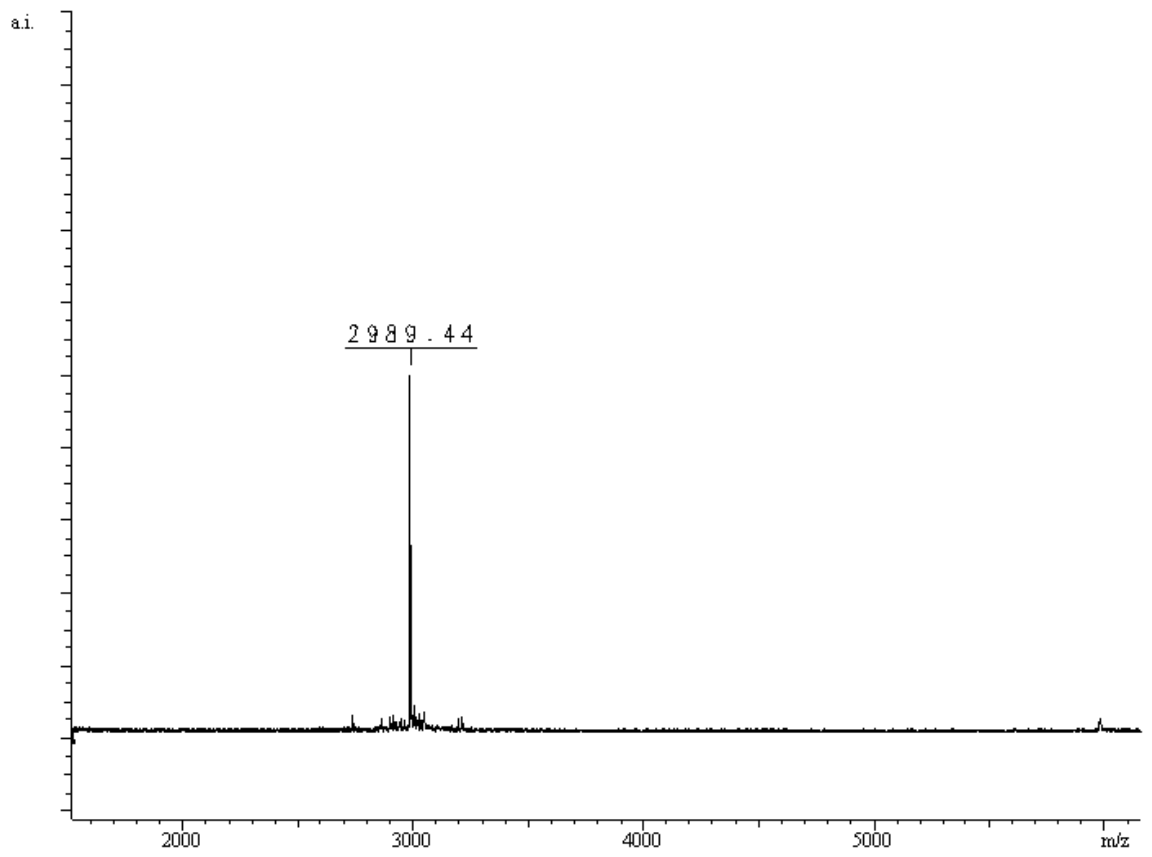

Figure S2. MALDI-TOF mass spectrum of HPLC purified 2.

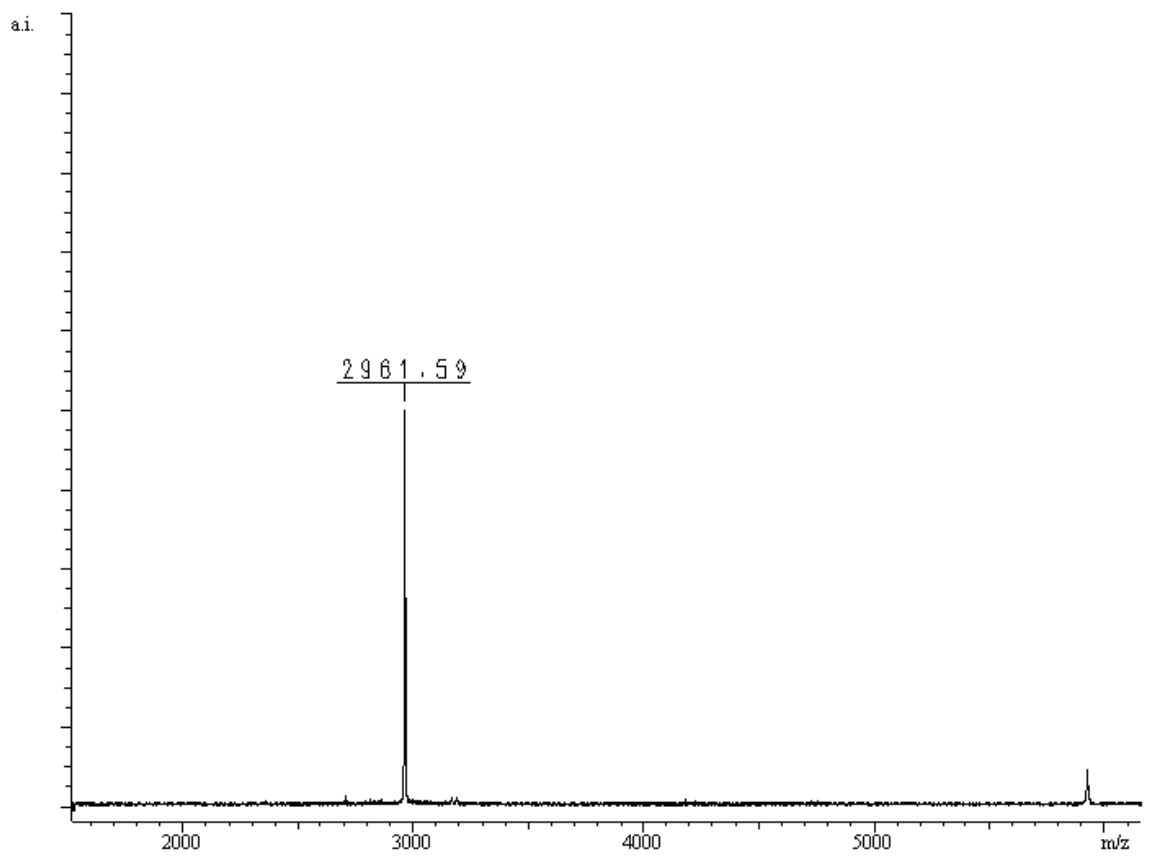

Figure S3. MALDI-TOF mass spectrum of HPLC purified 5. 


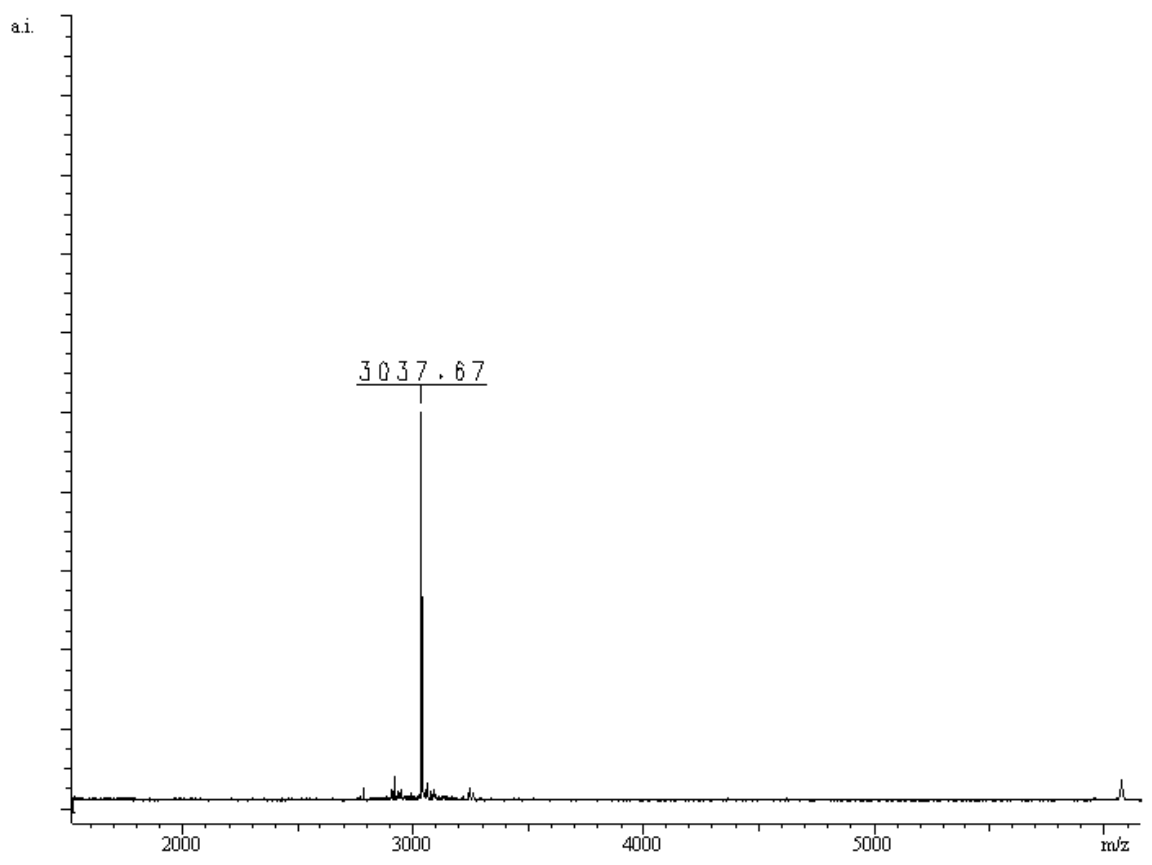

Figure S4. MALDI-TOF mass spectrum of HPLC purified 7.

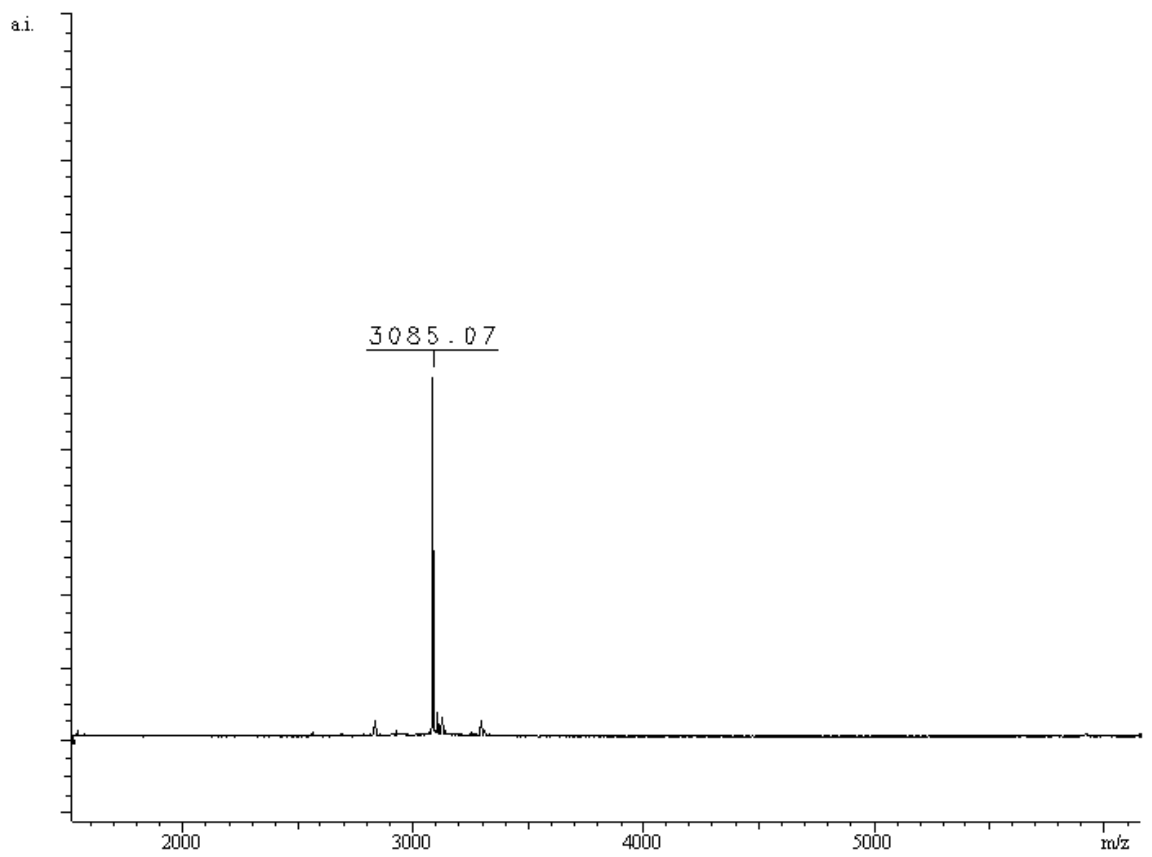

Figure S5. MALDI-TOF mass spectrum of HPLC purified 8. 


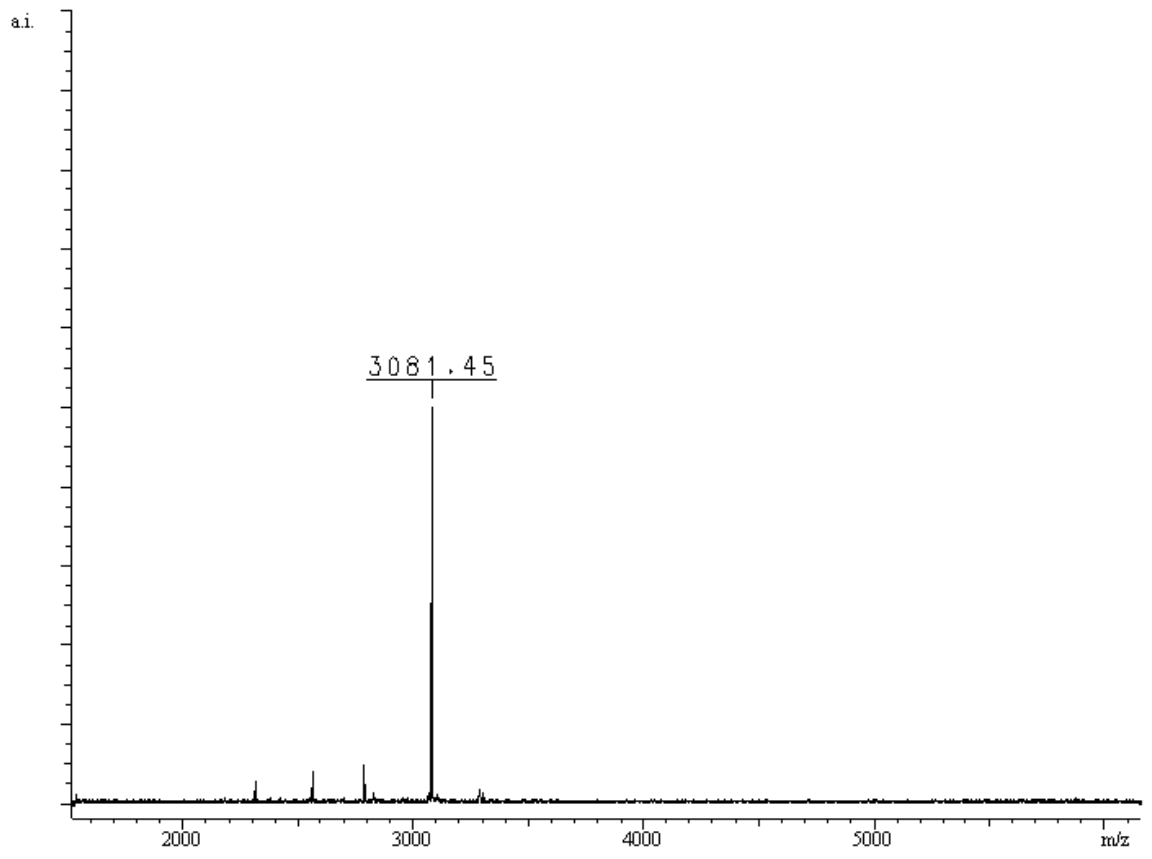

Figure S6. MALDI-TOF mass spectrum of HPLC purified 9.

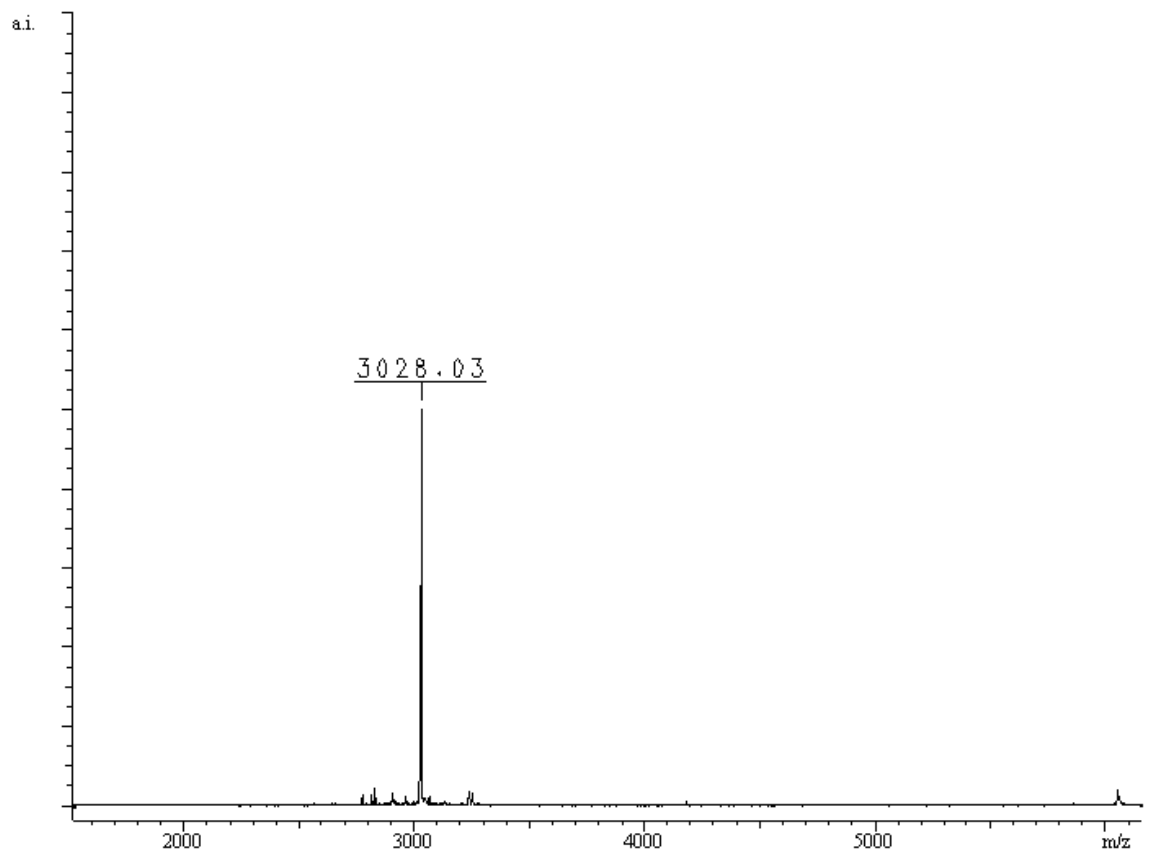

Figure S7. MALDI-TOF mass spectrum of HPLC purified 10. 


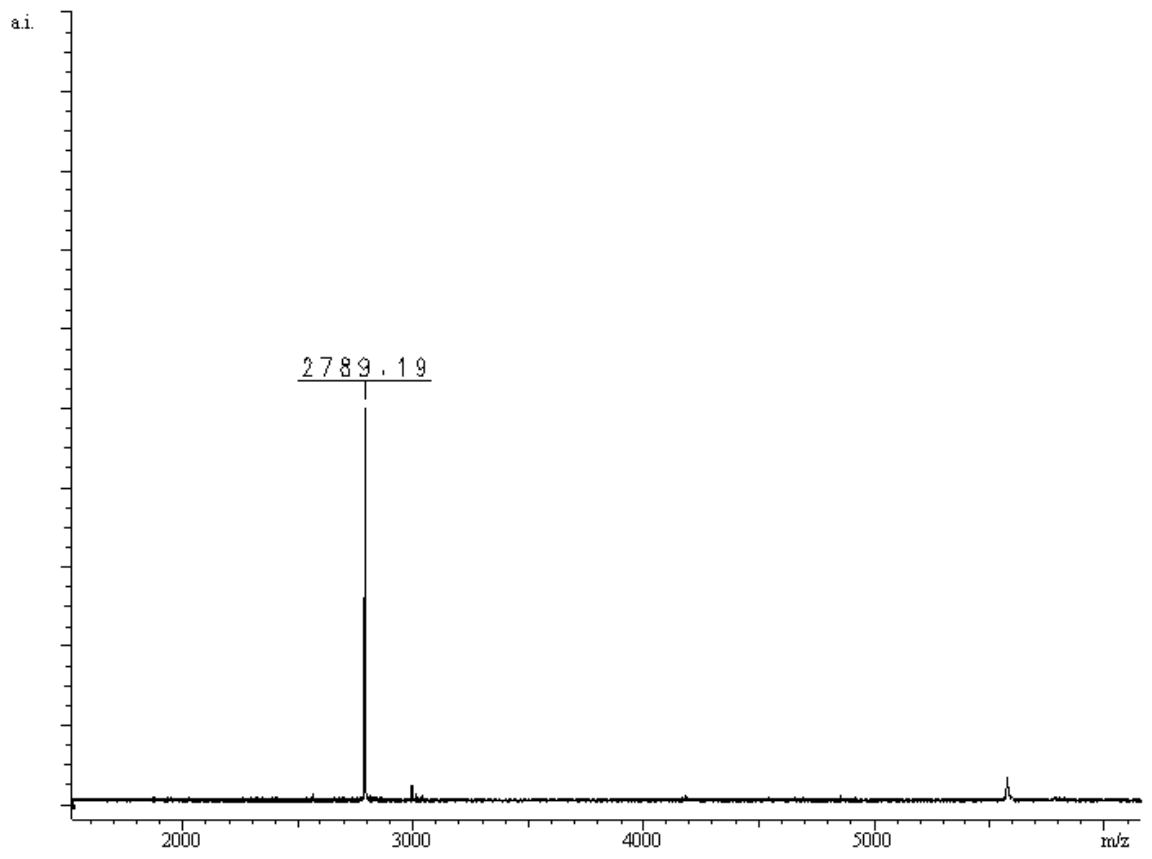

Figure S8. MALDI-TOF mass spectrum of HPLC purified 11. 

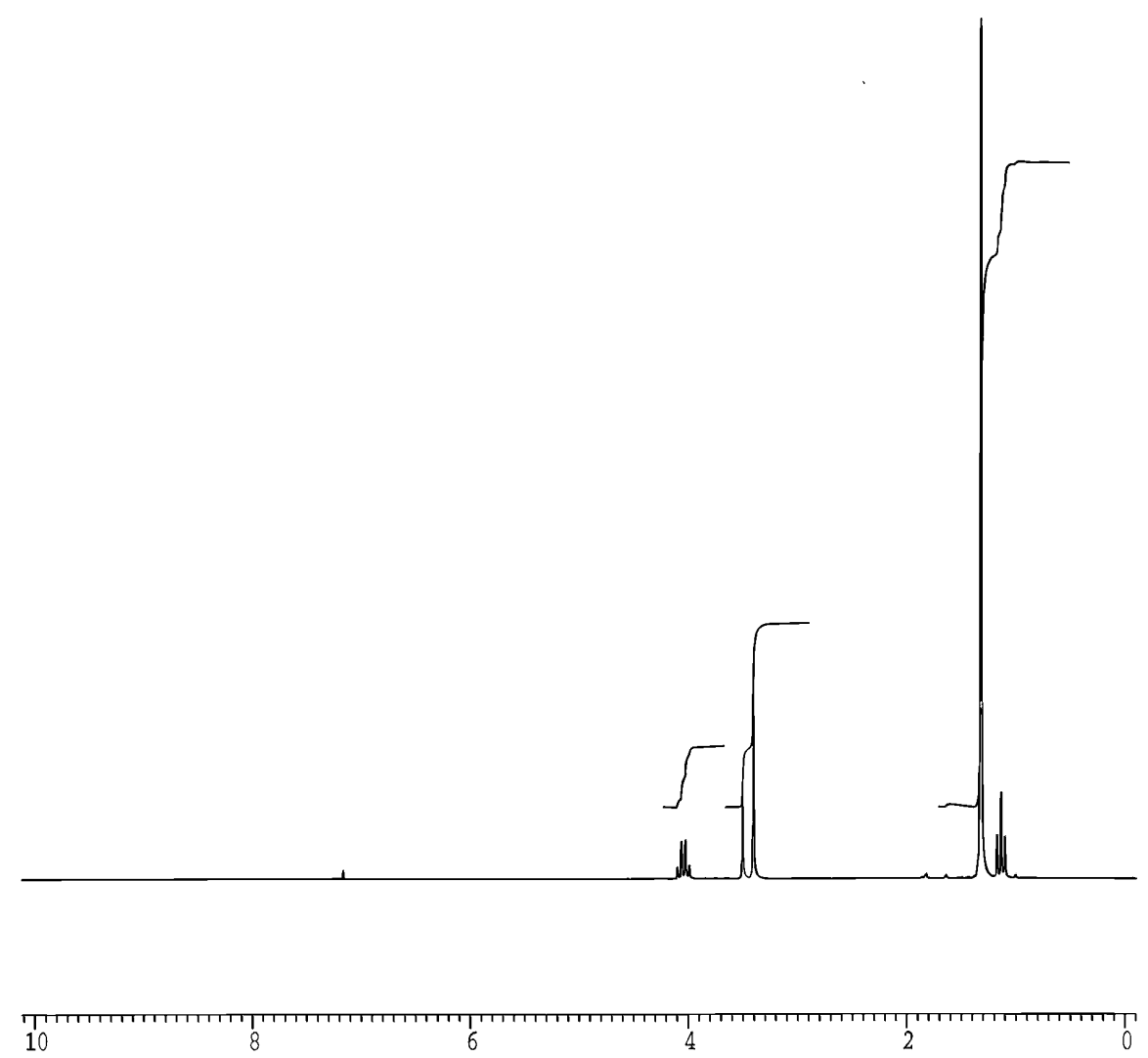

Figure S9. ${ }^{1} \mathrm{H}-\mathrm{NMR}$ of $\mathbf{1 5}$ in $\mathrm{CDCl}_{3}$.

Figure S10. ${ }^{13} \mathrm{C}-\mathrm{NMR}$ of $\mathbf{1 5}$ in $\mathrm{CDCl}_{3}$. 
Figure S11. ${ }^{1} \mathrm{H}-\mathrm{NMR}$ of $\mathbf{1 6}$ in $\mathrm{CDCl}_{3}$.

Figure S12. ${ }^{13} \mathrm{C}-\mathrm{NMR}$ of $\mathbf{1 6}$ in $\mathrm{CDCl}_{3}$. 
Figure S13. ${ }^{1} \mathrm{H}-\mathrm{NMR}$ of $\mathbf{1 7}$ in $\mathrm{d}^{6}$-DMSO. * is impurity.

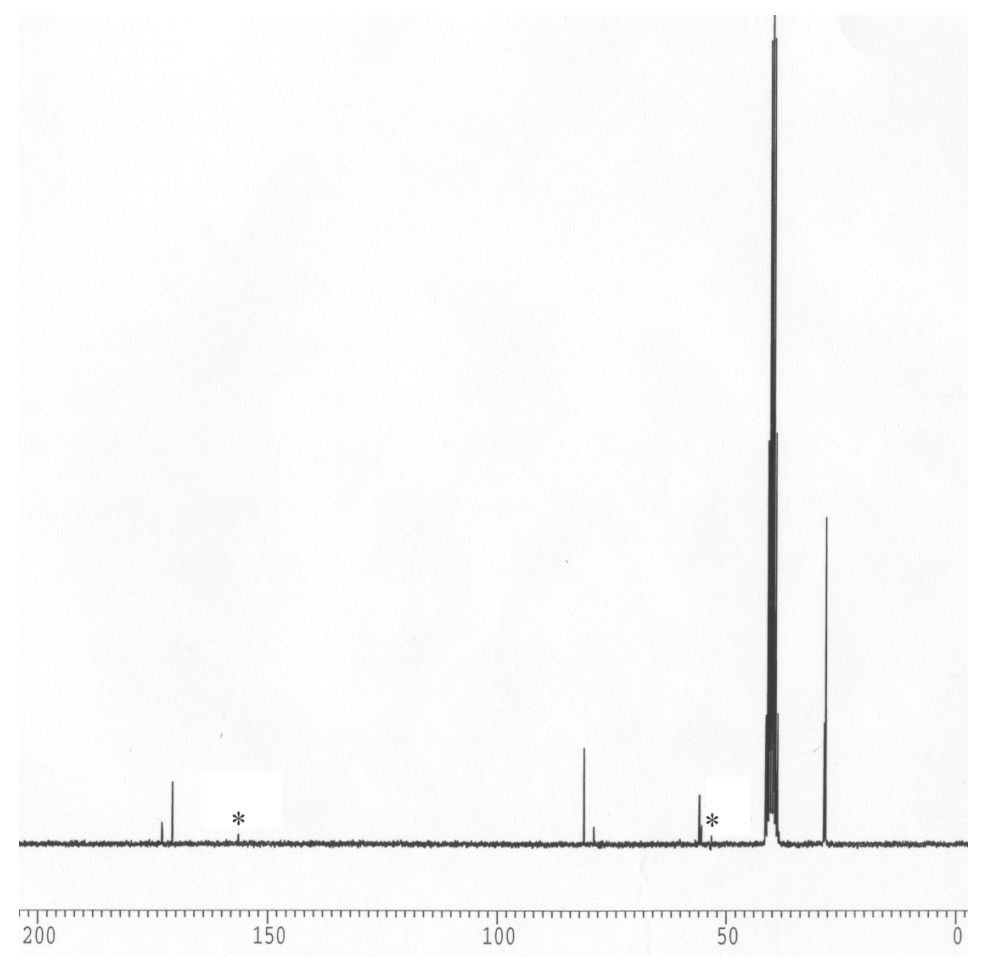

Figure S14. ${ }^{13} \mathrm{C}-\mathrm{NMR}$ of $\mathbf{1 7}$ in $\mathrm{d}^{6}$-DMSO. * is impurity. 

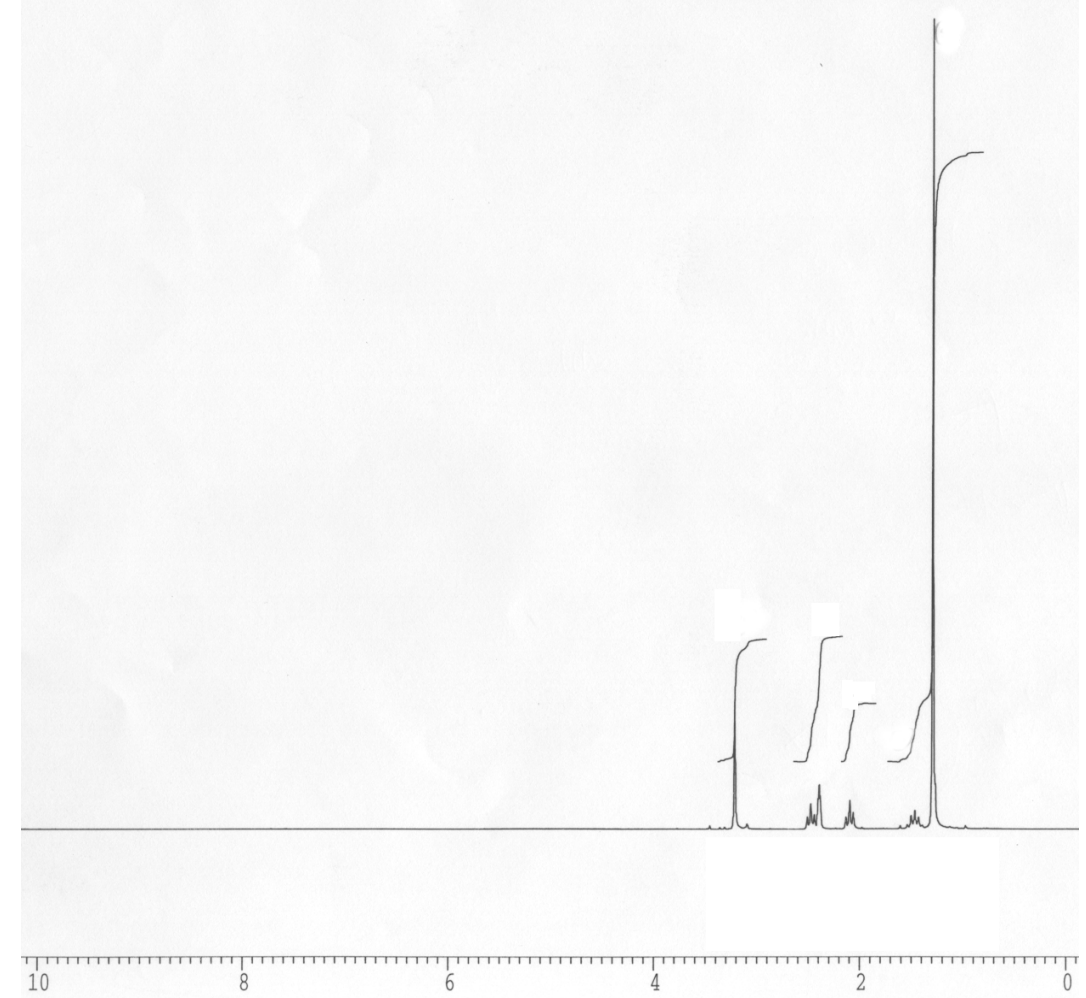

Figure S15. ${ }^{1} \mathrm{H}-\mathrm{NMR}$ of $\mathbf{1 8}$ in $\mathrm{d}^{6}$-DMSO.

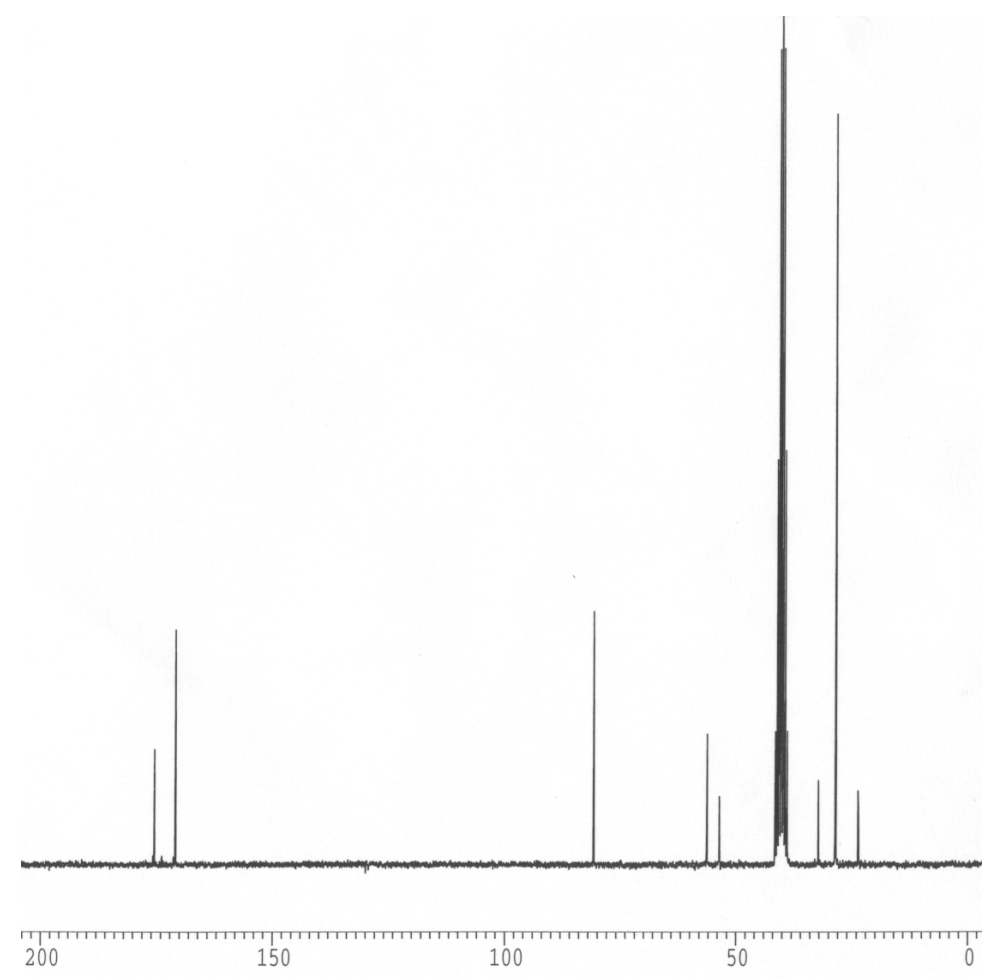

Figure S16. ${ }^{13} \mathrm{C}-\mathrm{NMR}$ of $\mathbf{1 8}$ in $\mathrm{d}^{6}$-DMSO. 


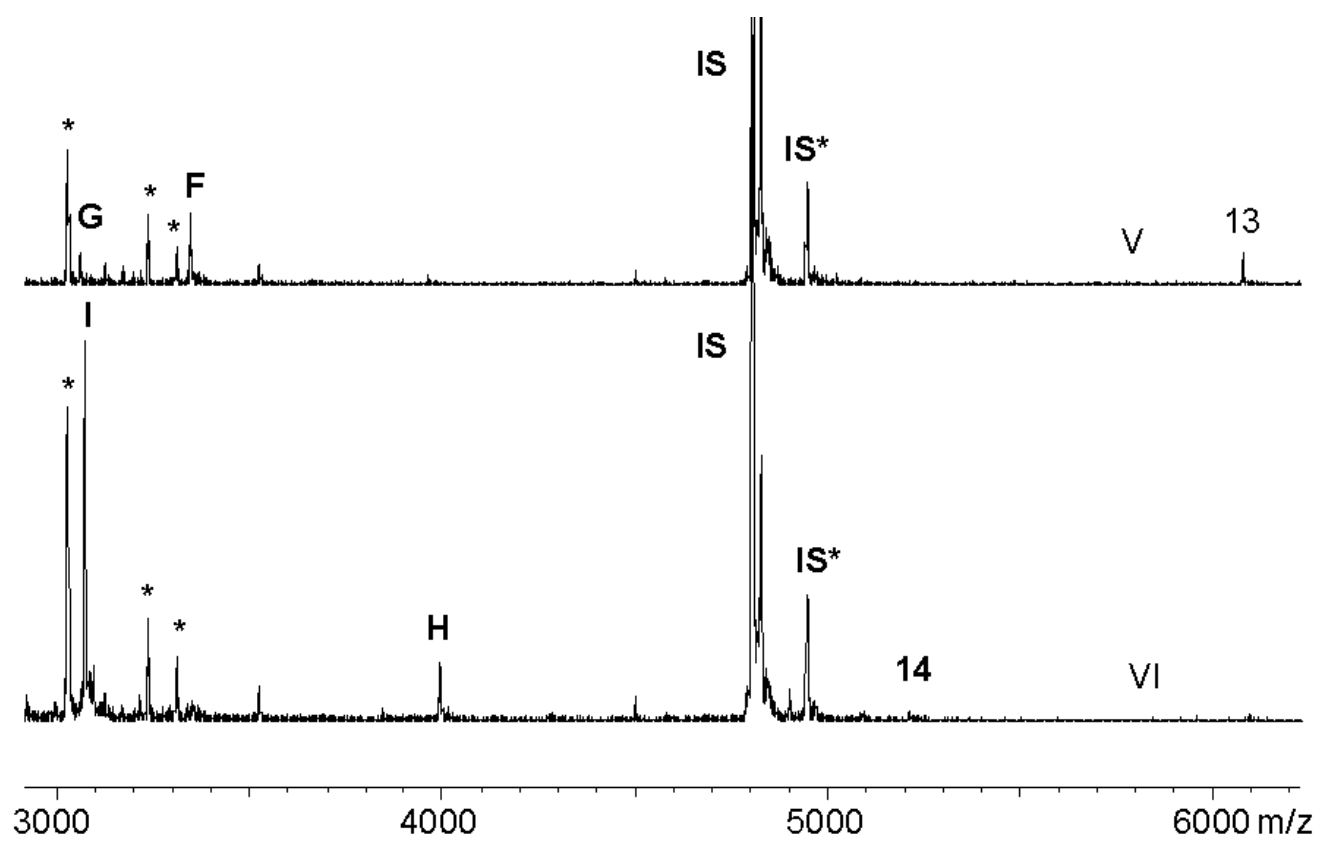

Figure S17. Cleavage of DNAs 13-14.

MALDI-TOF spectra were taken $164 \mathrm{~h}$ after reaction beginning; V: Cleavage of DNA 13 $(10 \mu \mathrm{M})$ by $10(10 \mu \mathrm{M}) / \mathrm{Zr}(\mathrm{IV})(100 \mu \mathrm{M})$. VI: Cleavage of $14(10 \mu \mathrm{M})$ by $10(10 \mu \mathrm{M}) / \mathrm{Zr}(\mathrm{IV})$ $(100 \mu \mathrm{M})$. IS: internal standard.*PNA, PNA-matrix, PNA-buffer and IS*; (Scheme 3).
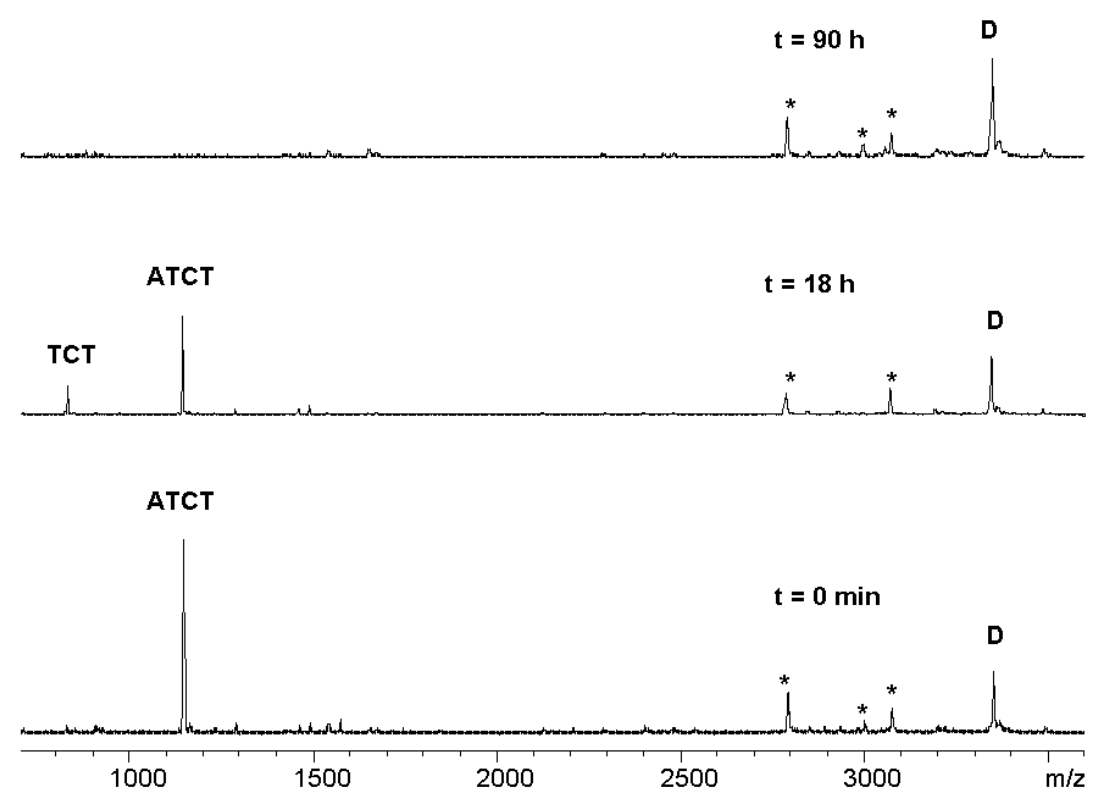

Figure S18. Cleavage of ATC T and TAG TTG TGA CC (mixture VII).

MALDI-TOF spectra were taken $0 \mathrm{~min}, 18 \mathrm{~h}$ and $90 \mathrm{~h}$ after reaction beginning; VII: Fragment D $(10 \mu \mathrm{M}), 4-m e r$ DNA (ATCT) $(2 \mu \mathrm{M})$ and $11(10 \mu \mathrm{M}) / \mathrm{Zr}(\mathrm{IV})(100 \mu \mathrm{M})$. 


\section{Description of the DNA cleavage reaction.}

The substrate DNA (12-14) $(10 \mu \mathrm{M})$, MOPS buffer $(5 \mathrm{mM}$; pH 7), PNA (1-11) $(10 \mu \mathrm{M})$ or unmodified PNA 11 in combination with $\mathbf{L}_{\mathbf{1 0}}-\mathrm{H}$ were added to water. The solution was vortexed and hydrolysis was initiated after $1-2 \mathrm{~h}$ by adding $\mathrm{ZrCl}_{4}(10,50$ or $100 \mu \mathrm{M})$. The final reaction volume was $10 \mu \mathrm{l}$ for II-VI and $200 \mu \mathrm{l}$ for I. At definite times, probes $(1 \mu \mathrm{l})$ were mixed on a MALDI target with the matrix solution (saturated ATT-solution in EtOH:DACsolution in water $(0,1 \mathrm{M})=1: 1$; containing internal DNA standard (IS:19-mer, poly-T; $1,35 \mu \mathrm{M}$, $1 \mu \mathrm{l})$ and allowed to dry in air. The reaction was performed at $\mathrm{T}=22^{\circ} \mathrm{C}+/-2^{\circ} \mathrm{C}$. The $\mathrm{pH}$ value was checked before, during and after the experiment in I.

\section{Description of the control experiment mixture VII.}

Fragment D $(10 \mu \mathrm{M})$, 4-mer DNA (ATCT) $(2 \mu \mathrm{M})$, MOPS buffer $(5 \mathrm{mM}$; pH 7$)$ and PNA 11 $(10 \mu \mathrm{M})$ were added to water. The solution was vortexed and hydrolysis was initiated after 1$2 \mathrm{~h}$ by adding $\mathrm{ZrCl}_{4}(100 \mu \mathrm{M})$. The final reaction volume was $200 \mu \mathrm{l}$. At definite times $(0 \mathrm{~min}$, $18 \mathrm{~h}, 90 \mathrm{~h})$, probes $(1 \mu \mathrm{l})$ were mixed on a MALDI target with the matrix solution (saturated ATT-solution in EtOH:DAC-solution in water $(0,1 \mathrm{M})=1: 1$; containing internal DNA standard (IS:19-mer, poly-T; $1,35 \mu \mathrm{M}, 1 \mu \mathrm{l}$ ) and allowed to dry in air. The reaction was performed at $\mathrm{T}=22^{\circ} \mathrm{C}+/-2^{\circ} \mathrm{C}$. The $\mathrm{pH}$ value was checked before, during and after the experiment in $\mathrm{I}$. 


\section{Synthesis of protected ligands 15-18}

\section{Bis-(N-tert-butyloxycarbonylmethyl)-amino-acetic acid ethyl ester 15}

Glycine ethylester hydrochloride (279.2mg; 2mmol) was dissolved in DMF (10ml) and diisopropylethylamine $(2 \mathrm{ml} ; 12 \mathrm{mmol})$. Bromo-acetic acid tert-butyl ester $(3.22 \mathrm{ml} ; 20 \mathrm{mmol})$ was added and the resulting solution was stirred at room temperature for 60 hours. Ethyl acetate $(50 \mathrm{ml})$ was added and the solution was washed with water $(3 \times 15 \mathrm{ml}) ; \mathrm{NaHCO}_{3}(10 \%$ $\mathrm{v} / \mathrm{v} ; 2 \times 10 \mathrm{ml})$ and brine $(3 \times 5 \mathrm{ml})$. The aqueous layer was washed with $\mathrm{CH}_{2} \mathrm{Cl}_{2}(4 \times 15 \mathrm{ml})$ and the combined organic layer was dried $\left(\mathrm{Na}_{2} \mathrm{SO}_{4}\right)$ and concentrated in vacuum. Flash chromatography $\left(2 \% \mathrm{EtOH} / \mathrm{CH}_{2} \mathrm{Cl}_{2}\right)$ on silica gel afforded 15 as a yellow-brown oil $(439 \mathrm{mg}$; $1.32 \mathrm{mmol} ; 66 \%):{ }^{1} \mathrm{H}-\mathrm{NMR}\left(\mathrm{CDCl}_{3} ; 200 \mathrm{MHz},\right) \delta 4.14\left(\mathrm{q},{ }^{3} \mathrm{~J}=7.18,2 \mathrm{H}\right), 3.58(\mathrm{~s}, 2 \mathrm{H}), 3.50$ (s, $4 \mathrm{H}), 1.42$ (s, 18H), $1.23\left(\mathrm{t},{ }^{3} \mathrm{~J}=7.18,3 \mathrm{H}\right) ;{ }^{13} \mathrm{C}-\mathrm{NMR}\left(\mathrm{CDCl}_{3} ; 50 \mathrm{MHz}\right) \delta 171.29,170.40$, $81.43,60.84,56.13,55.22,28.41,14.49$; mass spectrum $\left(\mathrm{CI}^{+}\right) \mathrm{m} / z 332.5(\mathrm{M}+\mathrm{H})^{+}$; theor. 332.41. Anal. Calcd for $\mathrm{C}_{16} \mathrm{H}_{29} \mathrm{NO}_{6}: \mathrm{C}, 57.99 ; \mathrm{H}, 8.82 ; \mathrm{N}, 4.23$. Found: $\mathrm{C}, 57.85 ; \mathrm{H}, 8.73 ; \mathrm{N}$, 4.43 .

\section{4-Bis-(N-tert-butyloxycarbonylmethyl)-amino-butyric acid ethyl ester 16}

The synthesis was performed with 4-amino-butyric acid ethylester hydrochloride $(328.4 \mathrm{mg}$; $2 \mathrm{mmol})$, diisopropylethylamine $(2 \mathrm{ml} ; 12 \mathrm{mmol})$ and bromo-acetic acid tert-butyl ester $(3.22 \mathrm{ml} ; 20 \mathrm{mmol})$ to a yellow-brown oil $(536.7 \mathrm{mg} ; 1.49 \mathrm{mmol} ; 74 \%)$ as described for $15:{ }^{1} \mathrm{H}$ NMR $\left(\mathrm{CDCl}_{3} ; 200 \mathrm{MHz},\right) \delta 4.09\left(\mathrm{q},{ }^{3} \mathrm{~J}=7.14,2 \mathrm{H}\right), 3.42(\mathrm{~s}, 4 \mathrm{H}), 2.73\left(\mathrm{t},{ }^{3} \mathrm{~J}=7.00,2 \mathrm{H}\right), 2.35(\mathrm{t}$, $\left.{ }^{3} \mathrm{~J}=7.37,2 \mathrm{H}\right), 1.77\left(\mathrm{~m},{ }^{3} \mathrm{~J}=7.21,2 \mathrm{H}\right), 1.43(\mathrm{~s}, 18 \mathrm{H}), 1.22\left(\mathrm{t},{ }^{3} \mathrm{~J}=7.18,3 \mathrm{H}\right) ;{ }^{13} \mathrm{C}-\mathrm{NMR}$ $\left(\mathrm{CDCl}_{3} ; 50 \mathrm{MHz}\right) \delta 173.85,170.72,81.30,60.49,56.00,53.57,32.00,28.80,23.40,14.51$; mass spectrum $\left(\mathrm{CI}^{+}\right) \mathrm{m} / z 360.3(\mathrm{M}+\mathrm{H})^{+}$; theor. 360.2. Anal. Calcd for $\mathrm{C}_{18} \mathrm{H}_{33} \mathrm{NO}_{6}: \mathrm{C}, 60.14$; H, 9.25; N, 3.90. Found: C, 59.98; H, 9.26; N, 4.20.

\section{Bis-(N-tert-butyloxycarbonylmethyl)-amino-acetic acid 17}

$15(21 \mathrm{mg} ; 63 \mu \mathrm{mol})$ was dissolved in $\mathrm{MeOH}(4 \mathrm{ml})$. Sodium hydroxide (2N; 2ml) was added and the solution was stirred for $4 \mathrm{~h}$ at room temperature and neutralized with the pyridinium form of dowex ion exchange resin. The solution was filtered, concentrated in vacuum and coevaporated with toluene $(2 \times 25 \mathrm{ml})$ to afford 17 as a colorless oil $(17.2 \mathrm{mg} ; 57 \mu \mathrm{mol} ; 91 \%):{ }^{1} \mathrm{H}$ NMR (d ${ }^{6}-\mathrm{DMSO} ; 200 \mathrm{MHz}$, $\delta 3.33$ (s, 4H), 3.24 (s, 2H), 1.29 (s, 18H); ${ }^{13} \mathrm{C}-\mathrm{NMR}\left(\mathrm{d}^{6}-\mathrm{DMSO}\right.$; $50 \mathrm{MHz}) \delta 172.99,170.67,81.01,78.8,55.93,28.90$; mass spectrum $\left(\mathrm{CI}^{+}\right) \mathrm{m} / z 304.3(\mathrm{M}+\mathrm{H})^{+}$; theor. 304.2. 


\section{4-Bis-(N-tert-butyloxycarbonylmethyl)-amino-butyric acid 18}

Synthesis of $\mathbf{1 8}$ is analogous to synthesis of $\mathbf{1 7}$. The synthesis was performed with $\mathbf{1 6}(20 \mathrm{mg}$; $56 \mu \mathrm{mol}), \mathrm{NaOH}(2 \mathrm{~N}, 2 \mathrm{ml})$ to afford 18 as a colorless oil $(17.1 \mathrm{mg}, 56 \mu \mathrm{mol} ; 92 \%):{ }^{1} \mathrm{H}-\mathrm{NMR}$ $\left(\mathrm{d}^{6}\right.$-DMSO; 200MHz, $\delta 3.21(\mathrm{~s}, 4 \mathrm{H}), 2.47\left(\mathrm{t},{ }^{3} \mathrm{~J}=7.68,2 \mathrm{H}\right), 2.10\left(\mathrm{t},{ }^{3} \mathrm{~J}=7.34,2 \mathrm{H}\right), 1,53(\mathrm{~m}$, $\left.{ }^{3} \mathbf{J}=7.08\right), 1.39(\mathrm{~s}, 18 \mathrm{H}) ;{ }^{13} \mathrm{C}-\mathrm{NMR}\left(\mathrm{d}^{6}-\mathrm{DMSO} ; 50 \mathrm{MHz}\right) \delta 175.73,171.30,80.74,56.30$, 53.63, 39.82, 32.18, 23,64; mass spectrum $\left(\mathrm{CI}^{+}\right) \mathrm{m} / \mathrm{z} 332,3(\mathrm{M}+\mathrm{H})^{+}$; theor. 332.4.

\section{Synthesis of PNAs 1, 2, 5, 7-11}

\section{Synthesis of unmodified polymer bound PNA :}

Synthesis of the unmodified solid-support bound PNA was performed on an expedite 8909 PNA/DNA synthesizer under standard conditions.

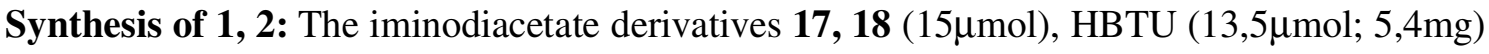
and HOBT $(15 \mu \mathrm{mol} ; 2 \mathrm{mg})$ were dissolved in DMF (500 $\mu \mathrm{l})$. DIEA $(33 \mu \mathrm{mol} ; 4,2 \mu \mathrm{l})$ was added and the solution was added to the unmodified solid-support bound PNA $(2.4 \mathrm{mg} ; 0,3 \mu \mathrm{mol}$ loading of solid support bound primary amine). This mixture was shaken for $1 \mathrm{~h}$ and filtered. The solid-support was washed with $\operatorname{DMF}(2 \times 1 \mathrm{ml})$, acetonitril $(2 \times 1 \mathrm{ml})$ and aceton $(2 \times 1 \mathrm{ml})$ and dried under vacuum $\left(10^{-2} \mathrm{mbar}\right)$.

Synthesis of 5 and solid support bound chloromethylbenzoyl-modified PNA (Scheme 2c): The synthesis is analogous to the synthesis of 1, 2. It was performed with 8-hydroxy-

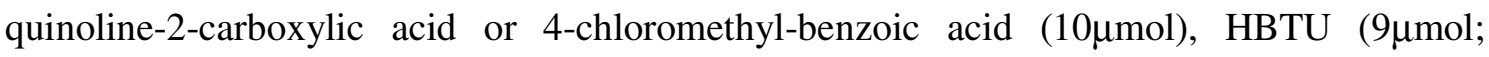
$3,6 \mathrm{mg})$, HOBT $(10 \mu \mathrm{mol} ; 1,35 \mathrm{mg})$ DIEA $(22 \mu \mathrm{mol} ; 2,84 \mu \mathrm{l})$, unmodified solid support bound PNA $(0.8 \mathrm{mg} ; 0,1 \mu \mathrm{mol}$ loading of solid support bound primary amine) and DMF $(500 \mu \mathrm{l})$.

Synthesis of 7: Di-tert-butyl iminodiacetate $(15 \mu \mathrm{mol} ; 3,6 \mathrm{mg})$, sodium iodode $(15 \mu \mathrm{mol}$; 2,2mg) and the solid support bound 4-chloromethylbenzoic acid modified PNA (2.4mg; $0,3 \mu \mathrm{mol}$ loading of solid support bound primary amine) were suspended in DMSO (500 $\mu 1)$. The mixture was shaken at $55^{\circ} \mathrm{C}$ for $12 \mathrm{~h}$ and filtered. The solid-support was washed with $\operatorname{DMF}(2 \times 1 \mathrm{ml})$, acetonitril $(2 \times 1 \mathrm{ml})$ and aceton $(2 \times 1 \mathrm{ml})$ and dried under vacuum $\left(10^{-2} \mathrm{mbar}\right)$.

Synthesis of 8-10. is analogous to synthesis of 7, but aminoalcohols glucamine, 1,3,5triamino-1,3,5-trideoxy-cis-inositol (TACI) and tris(hydroxymethyl)-aminomethan (TRIS) were used in place of di-tert-butyl iminodiacetate. 
Cleavage of PNAs from the solid support. TFA/ m-cresol $(4: 1 ; 200 \mu \mathrm{l})$ was added to the solid support bound PNA (0.8-2.4mg; 0.1-0.3 $\mu \mathrm{mol}$ loading of solid support bound primary amine). It was shaken for 90 minutes at room temperature and filtered. The PNA was precipitated with diethylether $(1 \mathrm{ml})$ and filtered. The pellet was washed with diethylether $(3 \mathrm{x}$ $1 \mathrm{ml})$, dried and purified using HPLC.

\section{Description of HPLC analysis of DNA cleavage reactions.}

The reaction mixture IV $(1 \mu \mathrm{l})$ was quenched with EDTA $(10 \mathrm{mM}$ in water, $1 \mu \mathrm{l})$. This solution was diluted with water $(10 \mu \mathrm{l})$ and analysed by HPLC. The injection volume was $10 \mu \mathrm{l}$. HPLC was on a EC $250 \times 4.6 \mathrm{~mm}$ Nucleosil 300-5 C4. Gradients of $\mathrm{CH}_{3} \mathrm{CN}$ (solvent B) and $0.1 \mathrm{M}$ triethylammoniumacetate in water ( $\mathrm{pH} 7 ; 0.1 \%$ EDTA) (solvent $\mathrm{A}$ ) were used: $5 \mathrm{~min}$ at $0 \% \mathrm{~B}$, in $30 \mathrm{~min}$ from $0-25 \% \mathrm{~B}$; in $10 \mathrm{~min}$ from $25-90 \% \mathrm{~B}, 9 \mathrm{~min}$ at $90 \% \mathrm{~B}$. 